J. Dairy Sci. 96:5811-5825

http://dx.doi.org/10.3168/jds.2013-6600

(C) American Dairy Science Association ${ }^{\circledR}, 2013$.

\title{
Calving body condition score affects indicators of health in grazing dairy cows
}

\author{
J. R. Roche, ${ }^{1}$ K. A. Macdonald, ${ }^{*}$ K. E. Schütz,† L. R. Matthews,‡ G. A. Verkerk, ${ }^{*}$ S. Meier, ${ }^{*}$ J. J. Loor,§ \\ A. R. Rogers,† J. McGowan, ${ }^{*}$ S. R. Morgan, ${ }^{*}$ S. Taukiri, ${ }^{*}$ and J. R. Webster† \\ *DairyNZ, Private Bag 3221, Hamilton 3240, New Zealand \\ †AgResearch, Private Bag 3123, Hamilton 3240, New Zealand \\ fLindsay Matthews and Associates Research International, Viale Mario Torinese 38, Scerne di Pineto, Teramo 64025, Italy, \\ and University of Auckland, Private Bag 92019, Auckland 1142, New Zealand \\ $\S$ Department of Animal Sciences, University of Illinois, Urbana 61801
}

\section{ABSTRACT}

The objectives of this study were to determine the effect of calving body condition score (BCS) on cow health during the transition period in a pasture-based dairying system. Feed inputs were managed during the second half of the previous lactation so that BCS differed at drying off (BCS 5.0, 4.0, and 3.0 for high, medium, and low treatments, respectively: a 10-point scale); feed allowance was managed after cows were dried off, such that the BCS differences established during lactation remained at the subsequent calving (BCS 5.5, 4.5, and 3.5; $\mathrm{n}=20,18$, and 19, for high, medium, and low treatments, respectively). After calving, cows were allocated pasture and pasture silage to ensure grazing residuals $>1,600 \mathrm{~kg}$ of $\mathrm{DM} / \mathrm{ha}$. Milk production was measured weekly; blood was sampled regularly pre- and postpartum to measure indicators of health, and udder and uterine health were evaluated during the 6 wk after calving. Milk weight, fat, protein, and lactose yields, and fat content increased with calving BCS during the first 6 wk of lactation. The effect of calving BCS on the metabolic profile was nonlinear. Before calving, cows in the low group had lower mean plasma $\beta$-hydroxybutyrate and serum $\mathrm{Mg}$ concentrations and greater mean serum urea than cows in the medium and high BCS groups, which did not differ from each other. During the 6 wk after calving, cows in the low group had lower serum albumin and fructosamine concentrations than cows in the other 2 treatment groups, whereas cows in the lowand medium-BCS groups had proportionately more polymorphonucleated cells in their uterine secretions at 3 and 5 wk postpartum than high-BCS cows. In comparison, plasma $\beta$-hydroxybutyrate and nonesterified fatty acid concentrations increased linearly in early

Received January 20, 2013.

Accepted May 25, 2013.

${ }^{1}$ Corresponding author: john.roche@dairynz.co.nz lactation with calving BCS, consistent with a greater negative energy balance in these cows. Many of the parameters measured did not vary with BCS. The results highlight that calving BCS and, therefore, BCS through early lactation are not effective indicators of functional welfare, with the analyses presented indicating that both low and high BCS at calving will increase the risk of disease: cows in the low group were more prone to reproductive compromise and fatter cows had an increased risk of metabolic diseases. These results are important in defining the welfare consequences of cow BCS.

Key words: health, transition cow, functional welfare, biomarker

\section{INTRODUCTION}

In a recent review, Roche et al. (2009) noted that the BCS in which a cow calves, her nadir BCS, and the amount of BCS she loses postpartum are associated with milk production, reproduction, and health. Body condition at calving was recognized as the most important point along the intercalving BCS profile, as, along with cow genetics, it dictated the extent of postpartum BCS loss and nadir BCS. It was also strongly related to milk production and the duration of the postpartum anestrous interval. By comparison, the influence of $\mathrm{BCS}$ on animal health and welfare was less clear.

Evidence exists that extremes of BCS at calving or a rapid loss of BCS after calving, or both, are associated with poor cow health (Garnsworthy, 2006; Roche and Berry, 2006; Berry et al., 2007; Roche et al., 2009). For example, high blood NEFA concentrations postpartum have been associated with impaired health (Markusfeld, 1985; Gillund et al., 2001), altered lymphocyte function (Lacetera et al., 2005), and impaired liver function (Drackley et al., 2001). Evidence also exists of relationships between energy balance, loss of BCS, and uterine infections (Huzzey et al., 2007; Burke et al., 2010; McDougall et al., 2011). For example, Huzzey 
et al. (2007) observed a strong negative relationship between risk of severe metritis after calving and both time spent feeding and DMI in the 2 wk before calving. Nevertheless, it remains unclear whether these relationships are associative or causal.

In Holstein-Friesian cows, recognized genetic correlations exist between milk production and BCS, and between milk production and health (Uribe et al., 1995; Berry et al., 2003; Ingvartsen et al., 2003; Coffey et al., 2004), such that genetic selection for increased milk yield appears to have resulted in more prolonged periods of lower BCS and greater disease morbidity. It can be inferred from these relationships that thinner cows might have an increased risk of poor health; it is not clear, however, whether this is due to a pleiotropic effect of genes associated with greater milk production, or if thinness per se results in poor health. It is also important to distinguish between healthy cows with a natural tendency for lower BCS and cows with low BCS due to chronic feed shortage or preexisting pathology. Although these 2 groups are likely to have differing physiology, behavior, and health, the question remains whether such differences are also evident where healthy animals have differing BCS. This point was highlighted by Matthews et al. (2012) when they reported that although a negative correlation existed between BCS and DMI, cows in all BCS categories exhibited similar amounts of time grazing and ruminating.

Despite the lack of objective evidence linking BCS to cow health and welfare, there is increasing public pressure to ensure that cows are not too thin. To this end, the objective of this study was to determine the effect of differing levels of BCS at calving (generated by dietary manipulation of healthy cows over the preceding late-lactation and early-dry periods) on selected indicators of animal health.

\section{MATERIALS AND METHODS}

The experiment was conducted at the DairyNZ Lye Farm (Hamilton, New Zealand; $37^{\circ} 76^{\prime} \mathrm{S} 175^{\circ} 37^{\prime} \mathrm{E}, 45 \mathrm{~m}$ above sea level) from January until September 2011. All procedures had prior approval of the Ruakura Animal Ethics Committee (Hamilton, New Zealand), in accordance with the New Zealand Animal Welfare Act 1999.

\section{General Approach to Establish Treatment Groups}

A group of 80 mid-lactation dairy cows of mixed age and breed were considered as candidates for the experiment. From these, 60 cows without previous history of disease, including mastitis, with confirmed pregnancy status, and having passed a veterinary clinical exami- nation, were enrolled in the experiment on February 1, 2011.

Cows were allocated randomly to treatment groups (20 cows per group), ensuring that treatments were balanced for age, breed, BCS at the time of enrolment, and expected calving date. Age at enrolment was $4.0 \pm 1.4$ yr (mean $\pm \mathrm{SD}$ ). Mean expected calving date was July $9 \pm 9 \mathrm{~d}$. Fourteen cows in each treatment were HolsteinFriesian; the remaining cows were Holstein-Friesian $\times$ Jersey crossbreds (75\% Holstein-Friesian/25\% Jersey cross).

From February 1, feeding levels were manipulated with the intention of generating 3 BCS groups before the end of lactation: target BCS at drying off was 5.0, 4.0, and 3.0 for high, medium, and low groups, respectively (based on a 10-point scale, where 1 is emaciated and 10 obese; Roche et al., 2004). Following drying off, cows were offered pasture and supplements to allow for fetal growth and a gain of 0.5 BCS units before calving, with the intention that mean calving BCS would be $5.5,4.5$, and 3.5 , for the high, medium, and low groups, respectively. This would be equivalent to $2.6,2.9$, and 3.3 in systems based on a 5-point scale; Roche et al., 2004).

During late lactation, daily feed allowances took into account the average BCS state of the group and the proposed trajectory of BCS change. Cows in the low, medium, and high treatment groups had an estimated daily DMI of fresh pasture of $6.8( \pm 1.69), 11.2( \pm 2.26)$, and $12.3( \pm 3.38) \mathrm{kg}$ of $\mathrm{DM}$, respectively. In addition to their daily allowance of pasture, cows were offered pasture silage, maize silage, and concentrate to facilitate the desired change in BCS. On average, during the period of BCS manipulation, cows in the low group received $1.9( \pm 1.03) \mathrm{kg}$ of pasture silage DM daily, cows in the medium group received $2.0( \pm 2.08) \mathrm{kg}$ of pasture silage DM, $0.5( \pm 0.90) \mathrm{kg}$ of maize silage $\mathrm{DM}$, and 1.0 $( \pm 1.03) \mathrm{kg}$ of concentrate DM daily, and cows in the high group received $2.4( \pm 2.04) \mathrm{kg}$ of pasture silage $\mathrm{DM}, 1.6( \pm 2.86) \mathrm{kg}$ of maize silage $\mathrm{DM}$, and $2.6( \pm 1.27)$ $\mathrm{kg}$ of concentrate DM daily (Table 1). Groups grazed the same paddock with electric fences separating them. Mean pasture DMI was calculated as the product of the difference between the pre- and postgrazing pasture mass and area grazed on $3 \mathrm{~d} / \mathrm{wk}$, as outlined by Roche et al. (2010). Estimated DMI (kg of DM/cow per day) during the treatment preparation period are provided in Table 1.

General management of the cows, including mineral and trace element supplementation, was in accordance with research farm practice. From May 30 to calving, cows were supplemented with $\mathrm{Mg}$ via the water reticulation system (Dosatron water dispensers; Bell-Booth 
Ltd., Palmerston North, New Zealand) at a rate calculated to provide $10 \mathrm{~g}$ of elemental $\mathrm{Mg} / \mathrm{cow}$ per day. They also received an oral $\mathrm{Mg}$ supplement weekly as $\mathrm{Mg}$ pidolate, an organic chelate purported to provide $\mathrm{Mg}$ for 5 to $7 \mathrm{~d}$ [100 mL of More-Mag; Dominion Chemicals (1988) Ltd., Auckland, New Zealand]. Following calving, cows received oral $\mathrm{Mg}$ salts, sufficient to provide 20 g elemental $\mathrm{Mg} / \mathrm{cow}$ per day.

During calving, at $1300 \mathrm{~h}$ each day, cows that had calved between $1000 \mathrm{~h}$ the previous day and $1000 \mathrm{~h}$ that day were collected from the pasture with their calves [except where cows had been observed having calving difficulty $(\mathrm{n}=2)$ or milk fever $(\mathrm{n}=2)$, which were attended to immediately]. Collection day was designated as the day of calving. Cows were milked twice per day. They entered a "colostrum herd" for their first 10 milkings. Provided no prevailing health issues existed, the cow was then transferred to the "milking herd." Following transfer to the milking herd, cows were managed as a single group. Cows were offered fresh pasture $(>35 \mathrm{~kg}$ of DM/cow per day to ground level) and supplemented with sufficient pasture silage to ensure that grazing residuals remained above $1,600 \mathrm{~kg}$ of $\mathrm{DM} / \mathrm{ha}$.

A total of 57 cows completed the experiment (20, 18, and 19 cows in the high, medium, and low groups, respectively). Results from the 3 cows that failed to complete the sampling schedule have been excluded. One died of misadventure in autumn, another aborted her pregnancy, and the third developed aspiration pneumonia after calving and was euthanized.

\section{Nutritional Analyses of Feed Samples}

Representative samples of pasture were collected daily by plucking pasture to grazing height from paddocks due to be grazed. Samples were bulked on a monthly basis precalving and on a weekly basis postcalving. Samples of supplementary feeds offered were collected on $3 \mathrm{~d}$ each week and bulked monthly. Duplicate samples of all feeds were dried at either $100^{\circ} \mathrm{C}$ for $\mathrm{DM}$ analysis or $60^{\circ} \mathrm{C}$ for analysis of nutrient composition. Feed samples oven dried at $60^{\circ} \mathrm{C}$ were ground to pass through a $0.5-\mathrm{mm}$ sieve (Christy Laboratory Mill, Suffolk, UK) and sent for chemical analysis to Dairy One Forage Laboratory Services (Ithaca, NY). Nutritional analyses of feeds offered are presented in Table 2.

\section{BCS Assessments and BW}

Body weights were recorded and BCS determined (10-point scale; Roche et al., 2004), by a minimum of 2 experienced assessors twice per week (Monday and Thursday) following the morning milking, or at approximately $0800 \mathrm{~h}$ during the nonlactating period. 
Table 2. Mean ( \pm SEM) nutrient composition (\% of DM, unless otherwise stated), macro-mineral concentration, trace-mineral $(\mathrm{mg} / \mathrm{kg}$ of $\mathrm{DM})$ concentration, DCAD $(\mathrm{mEq} / 100 \mathrm{~g}$ of $\mathrm{DM}), 24-\mathrm{h}$ in vitro total digestibility (IVTD 24 h), 24-h NDF digestibility (NDFD 24 h; \% of NDF), ME (MJ/kg of DM), and DM (\% fresh) of feeds offered throughout the experiment

\begin{tabular}{|c|c|c|c|c|}
\hline Item & Pasture & $\begin{array}{l}\text { Pasture } \\
\text { silage }\end{array}$ & Concentrate & $\begin{array}{l}\text { Maize } \\
\text { silage }\end{array}$ \\
\hline $\mathrm{CP}$ & $25.2(0.9)$ & $15.6(0.4)$ & 21.8 & 6.8 \\
\hline ADIN, $\%$ of $\mathrm{CP}$ & $1.7(0.1)$ & $1.02(0.05)$ & 6.3 & 0.5 \\
\hline NDIN, $\%$ of $\mathrm{CP}$ & $8.2(0.4)$ & $3.3(0.3)$ & 8.0 & 0.9 \\
\hline $\mathrm{ADF}$ & $27.3(1.1)$ & $38.1(0.5)$ & 22.3 & 22.5 \\
\hline NDF & $44.2(1.9)$ & $55.0(1.0)$ & 35.7 & 35.0 \\
\hline Lignin & $4.8(0.3)$ & $5.2(0.3)$ & 5.2 & 2.4 \\
\hline NFC & $24.2(1.8)$ & $17.6(1.2)$ & 34.5 & 51.7 \\
\hline Starch & $1.4(0.3)$ & $1.3(0.4)$ & 14.3 & 42.8 \\
\hline Crude fat & $4.0(0.2)$ & $4.1(0.2)$ & 5.7 & 3.0 \\
\hline Ash & $10.7(0.4)$ & $11.1(0.3)$ & 10.5 & 4.5 \\
\hline $\mathrm{Ca}$ & $0.74(0.05)$ & $0.55(0.02)$ & 0.70 & 0.16 \\
\hline $\mathrm{Cl}$ & $1.3(0.17)$ & $1.4(0.05)$ & 0.31 & 0.35 \\
\hline $\mathrm{Mg}$ & $0.24(0.02)$ & $0.18(0.003)$ & 0.29 & 0.10 \\
\hline $\mathrm{P}$ & $0.39(0.02)$ & $0.33(0.01)$ & 0.65 & 0.23 \\
\hline $\mathrm{K}$ & $3.4(0.09)$ & $2.8(0.1)$ & 0.87 & 1.11 \\
\hline $\mathrm{Na}$ & $0.20(0.02)$ & $0.16(0.01)$ & 0.28 & 0.02 \\
\hline $\mathrm{S}$ & $0.4(0.02)$ & $0.21(0.003)$ & 0.31 & 0.1 \\
\hline $\mathrm{Fe}$ & $94.5(6.4)$ & $578(83.3)$ & 1,048 & 242 \\
\hline $\mathrm{Zn}$ & $43.5(1.9)$ & $36.3(1.0)$ & 203 & 32 \\
\hline $\mathrm{Cu}$ & $8.2(0.7)$ & $7.0(0.9)$ & 24.5 & 6 \\
\hline $\mathrm{Mn}$ & $45(2.2)$ & $97.0(8.5)$ & 110 & 27 \\
\hline Mo & $1.1(0.2)$ & $1.2(0.1)$ & 1.4 & 0.35 \\
\hline DCAD & $33.2(4.5)$ & $26.8(1.8)$ & 6.5 & 13 \\
\hline IVTD $24 \mathrm{~h}$ & $82.5(2.3)$ & $76.7(0.8)$ & 75.5 & 77 \\
\hline NDFD $24 \mathrm{~h}$ & $61(4.1)$ & $57.7(1.6)$ & 31.5 & 35 \\
\hline $\mathrm{ME}$ & $12.0(0.4)$ & $11.1(0.1)$ & 10.8 & 11.1 \\
\hline $\mathrm{DM}$ & & $29.6(6.6)$ & 34.1 & 90.1 \\
\hline
\end{tabular}

All BCS assessors were trained and recalibrated at the start of the experiment following the procedures set out in Macdonald and Roche (2004). The interobserver variance component for BCS estimates was 0.05 (SD $=0.2$ ).

\section{Blood Sampling Regimen}

Cows were blood sampled weekly from 2 wk before calving (wk -2 and -1 ) to 6 wk postpartum (wk 1-6). Blood samples were obtained by coccygeal venipuncture into evacuated tubes that contained heparin, EDTA, sodium fluoride, or no anticoagulant (Vacutainer; Becton Dickinson, Franklin Lakes, NJ).

Samples containing heparin and sodium fluoride anticoagulant were placed immediately into iced water and centrifuged within $60 \mathrm{~min}$ at 1,500 $\times g$ for $12 \mathrm{~min}$ at $4^{\circ} \mathrm{C}$. Samples in plain tubes were held at ambient temperature following collection for at least $2 \mathrm{~h}$ to allow serum to separate before centrifugation at $1,500 \times g$ for $12 \mathrm{~min}$ at $4^{\circ} \mathrm{C}$. Following centrifugation, plasma and serum were aspirated, and aliquots stored at $-20^{\circ} \mathrm{C}$ until assayed.

Further samples (EDTA and plain tubes) were held at ambient temperature and delivered within $3 \mathrm{~h}$ to
Gribbles Veterinary Pathology Ltd. (Hamilton, New Zealand) for estimation of plasma BHBA and NEFA, fibrinogen, and total and differential white blood cell (WBC) counts. Results of these analyses were available for all samples for each cow. Fifteen cows per treatment were selected randomly for analysis of the other metabolite and health indicators.

\section{Colostrum and Milk Sampling and Analyses}

At the first and tenth milkings, and when clinical mastitis was detected, quarter milk samples were collected using an aseptic technique for bacterial culture. Somatic cell counts were also estimated in samples from the tenth milking. Individual milk yields $(\mathrm{kg})$ from all cows were measured at each milking using a GEA milking system and its associated DairyPlan C21 herd and parlor management software (GEA Farm Technologies Ltd., Cambridge, New Zealand). Milk samples were collected weekly from wk 1 to 6 as a composite of consecutive afternoon and morning milkings for composition analysis and SCC. Milk composition was determined in the weekly samples by infrared analysis (FT120; Foss Electric A/S, Hillerød, Denmark). Somatic cells were enumerated using an electronic fluorometric cell- 
counting technique (Fossomatic; Foss Electric A/S) by Livestock Improvement Corp. Ltd. (Hamilton, New Zealand). Identification of bacteria in quarter samples of colostrum and milk was performed using the recommended procedures of Hogan et al. (1999).

\section{Analysis of Plasma and Serum Samples}

Metabolite assays were performed using colorimetric techniques at $37^{\circ} \mathrm{C}$ with a Hitachi Modular P800 analyzer (Roche Diagnostics, Indianapolis, IN) by Gribbles Veterinary Pathology Ltd. Roche reagent kits were used to measure serum concentrations of albumin $(\mathrm{g} / \mathrm{L}$; bromocresol green reaction at $\mathrm{pH} 4.1)$, aspartate aminotransferase (ASAT; IU/L; conversion of $\alpha$-oxoglutarate and L-aspartate to L-glutamate and oxaloacetate), $\mathrm{Ca}$ (mmol/L; $\sigma$-cresolphthalein complexone method), creatinine $(\mu \mathrm{mol} / \mathrm{L}$; enzymatic assay measuring conversion to sarcosine, and liberation of hydrogen peroxide via modified Trinder method to form a quinine imine chromogen), fibrinogen ( $\mathrm{g} / \mathrm{L}$; heat precipitation method based on Millar et al., 1971), fructosamine $(\mu \mathrm{mol} / \mathrm{L}$; reduction of nitrotetrazolium blue to formazan, in alkaline solution), glutamate dehydrogenase (GDH; IU/L; reduction of $\alpha$-oxoglutarate), $\gamma$-glutamyl transferase (GGT; IU/L; production of 5-amino-2-nitrobenzoate), $\mathrm{Mg}$ ( $\mathrm{mmol} / \mathrm{L}$; xylidyl blue reaction), phosphate $\left(\mathrm{PO}_{4} ; \mathrm{mmol} / \mathrm{L}\right.$; ammonium molybdate UV method), total protein (TP; g/L; biuret method), and urea (mmol/L; urease hydrolysis method based on formation of glutamate and NAD), and plasma concentrations of glucose $(\mathrm{mmol} / \mathrm{L}$; glucose oxidase method) and BHBA (mmol/L; reduction of NAD to NADH during oxidation of D-3-hydroxybutyrate to acetoacetate).

Serum amyloid $\alpha$ (SAA; $\mu \mathrm{g} / \mathrm{mL})$ concentrations were measured using Eiken Chemical Co. Ltd. (Tokyo, Japan) kit no. 18005 based on turbidimetric measurement of the latex agglutination reaction. Serum haptoglobin concentrations $(\mathrm{g} / \mathrm{L})$ were measured using Tridelta Development Ltd. (Co. Kildare, Ireland) phase kit no. TP801 based on colorimetric determination of peroxidase activity of hemoglobin at low $\mathrm{pH}$. Plasma NEFA concentrations $(\mathrm{mmol} / \mathrm{L})$ were measured using WAKO Chemicals (Osaka, Japan) kit NEFA HR2, measuring oxidative condensation of 3-methyl-N-ethyl$\mathrm{N}$-( $\beta$-hydroxyethyl)-aniline with 4-aminoantipyrine. The inter- and intraassay coefficient of variation for assays using the modular system were between 0.8 and $5.3 \%$, and 0.5 and $15 \%$, respectively.

Total WBC counts were estimated using an ADVIA 120 Hematology Analyzer (Global Medical Instrumentation Inc., Anoka, MN) based on laser optics to measure light absorption and scatter in combination with a peroxidase cytochemical reaction and myeloperoxidase staining. The inter- and intraassay coefficients of variation were 4.0 and $2.7 \%$, respectively. Differential cell counts were performed by microscopic examination of 100 WBC per sample in air-dried blood smears following staining with Leishman's stain by veterinary pathologists at Gribbles Veterinary Pathology Ltd. Assay coefficients of variation for differential cell counts were $9.4 \%$ for neutrophils and $14.7 \%$ for lymphocytes.

\section{Uterine Cytology}

Samples of endometrial fluid were collected for cytological examination from all cows using the technique described by Burke et al. (2010). Material recovered in uterine swabs was smeared onto microscope slides and air dried. Slides were fixed and stained (Diff-Quik; Dade Behring Inc., Newark, DE) within $1 \mathrm{~h}$ of collection and then examined by a veterinary pathologist [Institute of Veterinary, Animal and Biomedical Sciences (IVABS), Massey University, Palmerston North, New Zealand]. Areas of each slide that contained small clusters of epithelial cells (5-20 cells per cluster) were preferentially selected and all intact identifiable nucleated cells were counted in these fields. Approximately 200 nucleated cells per slide were enumerated, with PMNL distinguished from non-PMNL cells, to allow the proportions of nucleated cells that were PMNL to be calculated (Barlund et al., 2008).

\section{Reproduction Management}

The rebreeding period commenced in mid September (70 DIM) and continued for 10 wk. Ten cows not observed to have been in estrus after 3 wk following the commencement of breeding $(1,2$, and 5 cows from high, medium, and low groups, respectively) were treated with an estrus synchronization program to which they all responded with an observed estrus and were bred. Following the breeding period, cows were examined twice by transrectal ultrasonography to determine their pregnancy status $(\sim 60$ and $110 \mathrm{~d}$ after the onset of breeding).

\section{Calculations and Statistical Analyses}

Data for serum globulin concentrations were derived by subtraction of serum albumin from total protein in each sample. Data for ratios (serum albumin:globulin and serum fructosamine:albumin) were calculated. Values for SAA below the assay threshold of $1 \mathrm{~g} / \mathrm{L}$ were ascribed as $0.5 \mathrm{~g} / \mathrm{L}$ for statistical analyses.

Preexperimental BCS, BW, and milk production data from January 2011 were used as covariates for 
analyses of BCS, BW, and milk production variables, respectively. Data for plasma BHBA, NEFA, leukogram components, serum levels of liver enzymes and haptoglobin, and milk SCC were $\log _{10}$ transformed before analysis. Data for PMNL percentage were angular transformed before analysis.

Data were analyzed using GenStat v14.1 (VSN International Ltd., 2011). Data for BCS and BW were analyzed separately for the preparatory period to June 1 , and for the postpartum period (wk 1-6). Data for metabolites were analyzed within the 2 periods described by the sampling regimen (i.e., wk -2 and -1 before calving and the first 6 wk of lactation).

Mixed models were fitted with REML and included fixed effects for age group (3 yr old and "rest"), week of experiment, treatment, and time $\times$ treatment interactions, using a compound symmetry covariance structure for within cow repeated measurements. To check that this covariance structure was adequate, the repeated measurements through time were also modeled using spline models within the linear mixed model framework as described by Verbyla et al. (1999). Age group, treatment, the linear trend of week, and the interaction of treatment with the linear trend of week were included in the model as fixed effects. Cow, linear trend of week within cow, spline, the interaction of cow with spline, and the interaction of treatment with spline were included as random effects. Residual maximum likelihood (REML) in GenStat 14.1 was used to fit these models. Results from both fitted models were similar, so the results from the first of these analyses are presented.

Proportional data for uterine measurements were analyzed using generalized linear models with binomial error distribution and logit link. Reproduction interval data were analyzed using the censor procedure in GenStat 14.1. Proportional data for prevalence of clinical conditions were not analyzed, as the population sample was insufficient to infer clinical disease prevalence.

\section{RESULTS AND DISCUSSION}

The purpose of the experiment was to compare metabolic and clinical indicators of health in cows calving with differing levels of adiposity based on BCS assessment. The principal novelty of the study presented is that BCS was deliberately manipulated during mid and late lactation to generate groups with differing BCS at drying off (Figure 1). All cows were offered a feed allowance to guarantee that the calving BCS of 3.5, 4.5, and 5.5 were achieved 1 mo before calving and to ensure that energy balance in the weeks immediately precalving was not different between BCS treatment groups; this ensured that the effect of calving BCS was not confounded with precalving feeding level, a factor that has been reported to affect indices of health in other studies (Loor et al., 2006). The lack of effect of treatment on precalving NEFA and glucose concentrations confirms that treatment groups were similar in their energy balance in the weeks precalving.

The effects of calving BCS on BCS and BW change and milk production are consistent with previous reports (Broster and Broster, 1998; Stockdale, 2001; Garnsworthy, 2006; Roche et al., 2009). Mean BCS and BW were affected by treatment and week $(P<0.001)$ in both the pre- and postpartum periods (Figure 1a-d). In the postpartum period, a treatment by time interaction $(P<0.001)$ was observed for BW: cows from the low group gained $6 \mathrm{~kg} /$ cow between wk 2 and 6 , whereas cows in the medium and high groups lost 3.9 and $21.5 \mathrm{~kg}$, respectively (Figure 1d). Milk production differences recorded in the first 6 wk of lactation are also consistent with those reported for cows in pasturebased systems (Stockdale, 2001; Roche et al., 2009). Milk yield; yields of fat, protein, and lactose; and fat content increased linearly $(P<0.001$; Table 3$)$ with BCS. The rate of decline in milk fat content over wk 1 to 6 tended to be greater in the medium BCS cows than the other 2 groups $(P=0.07$; Figure $2 \mathrm{a})$.

\section{Clinical Health Events and Characteristics of the Leukon}

No clinical health events occurred before calving. From calving to wk 6, milk fever and clinical mastitis were the most common clinical ailments (Table 4). Although, numerical differences existed between treatments in the proportion of cows affected by clinical events and in the proportion of cows whose serum haptoglobin and amyloid $\alpha$ concentrations were above their clinical reference thresholds, no evident effect of BCS existed on the frequency of clinical health events.

Total and differential leukocyte counts were measured as potential indicators of inflammation and response to infection (Malmo et al., 2010). The only effect of BCS on leukon components was detected in the prepartum samples, when the mean count of segmented neutrophils tended $(P=0.09)$ to be lower in low-BCS cows $(3.5 \times$ $10^{9}, 3.6 \times 10^{9}$, and $3.0 \times 10^{9}$ cells/L for high, medium, and low groups, respectively) and the proportion of cows exhibiting neutrophilia was numerically lower in low-BCS cows (Table 4), even though the proportion of cows exhibiting leukocytosis was numerically greater. In around $50 \%$ of the cases, where an individual total WBC or segmented neutrophil count fell outside the clinical range, the event was associated with clinical disease, but no association existed between these and BCS treatment (Table 4).

These results are consistent with previous studies of the leukon in dairy cows. Rafia et al. (2012) compared 
Table 3. Mean yields of milk and milk components (kg/d) and milk composition (\%) during wk 1 to 6 of lactation for cows calving at BCS (10-point scale; Roche et al., 2004) 5.5 (high; $\mathrm{n}=20$ ), 4.5 (medium; $\mathrm{n}=$ 18), and 3.5 (low; $\mathrm{n}=19$ )

\begin{tabular}{|c|c|c|c|c|c|}
\hline \multirow[b]{2}{*}{ Item } & \multicolumn{3}{|c|}{ BCS } & \multirow[b]{2}{*}{$\mathrm{SED}^{1}$} & \multirow[b]{2}{*}{$P$-value } \\
\hline & High & Medium & Low & & \\
\hline \multicolumn{6}{|l|}{ Yield } \\
\hline Milk & 23.2 & 22.8 & 20.2 & 0.62 & $<0.001$ \\
\hline Fat & 1.12 & 1.03 & 0.67 & 0.04 & $<0.001$ \\
\hline Protein & 0.83 & 0.80 & 0.74 & 0.03 & $<0.01$ \\
\hline Lactose & 1.13 & 1.10 & 0.98 & 0.03 & $<0.001$ \\
\hline \multicolumn{6}{|c|}{ Composition } \\
\hline Fat & 4.85 & 4.57 & 4.28 & 0.10 & $<0.001$ \\
\hline Protein & 3.58 & 3.57 & 3.63 & 0.06 & 0.50 \\
\hline Lactose & 4.87 & 4.85 & 4.80 & 0.03 & 0.18 \\
\hline
\end{tabular}

${ }^{1}$ Standard error of the difference.

cows calving at a range of BCS and reported a weak negative association between monocyte counts and BCS, but no overall effect of BCS on leukon values. Measurement of leukon responses is most applicable to diagnosis of specific inflammatory or infectious conditions in individual animals; therefore, the lack of a treatment effect is consistent with the absence of differences in the incidence of clinical disease between treatment groups.
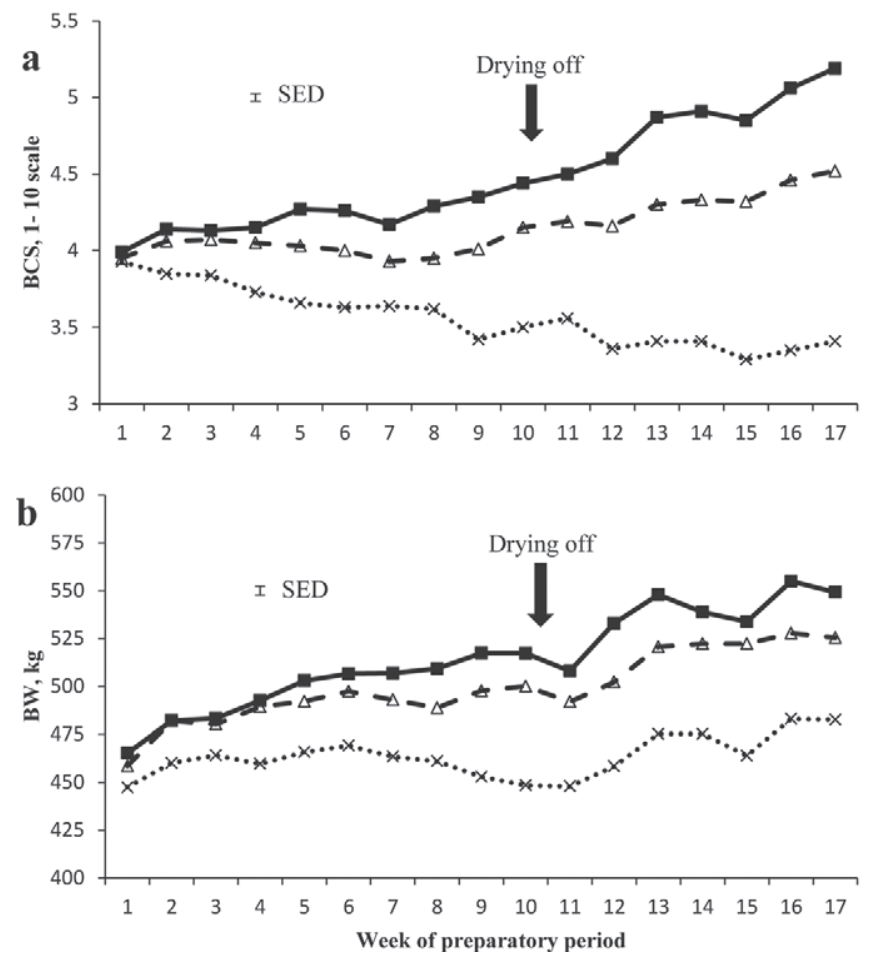

\section{Indicators of Energy Metabolism}

Plasma concentrations of BHBA, NEFA, glucose, and fructosamine were measured as indicators of energy metabolism and the extent of mobilization of adipose reserves in early lactation. Treatment effects on serum metabolites were consistent with the BCS and BW changes noted earlier. Before calving plasma BHBA concentrations were lower $(P<0.05)$ in cows in the low
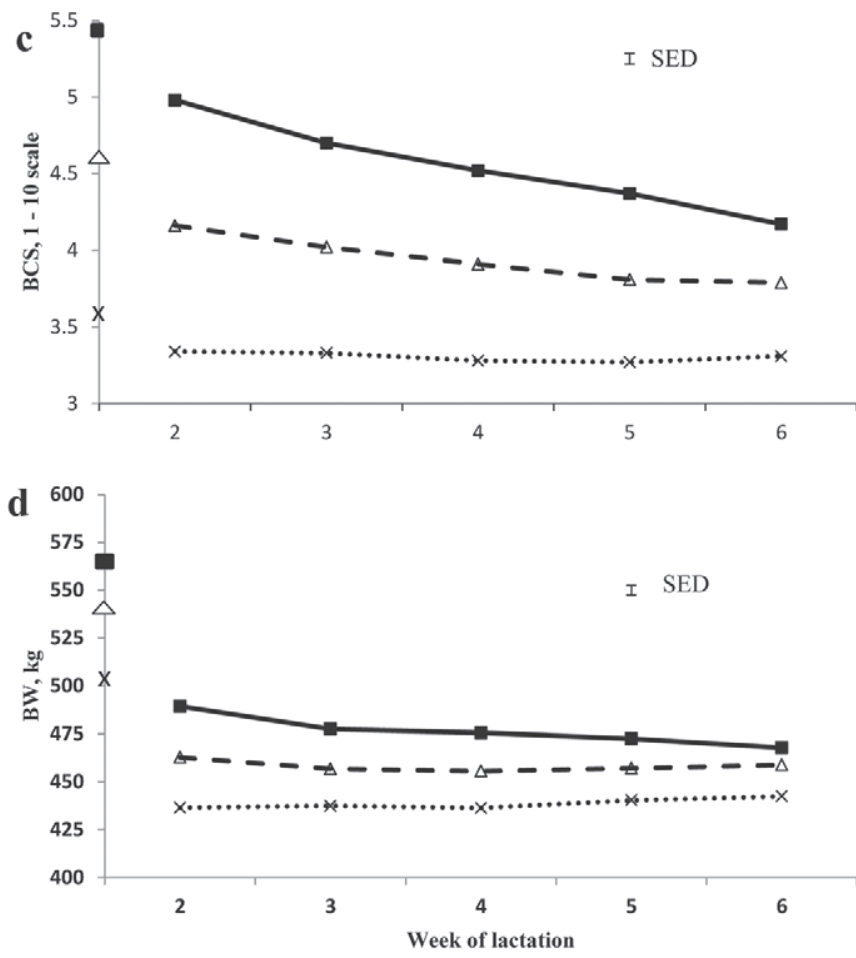

Figure 1. Mean BCS (10-point scale; Roche et al., 2004) and BW (kg) during the preparatory period (February to May; a and b, respectively) and following calving (c and d, respectively) for cows calving at BCS 5.5 (high; - $-; \mathrm{n}=20$ ), 4.5 (medium; - - $\Delta--; \mathrm{n}=18$ ), and 3.5 (low; $\cdots \times \cdots ; \mathrm{n}=19)$. Data points plotted over the $\mathrm{y}$-axis in $\mathrm{c}$ and $\mathrm{d}$ represent mean BCS and BW before calving, respectively. Error bars represent the SE of the difference (SED). 
Table 4. Proportions (\%) of cows affected by clinical conditions occurring from calving to wk 6 , with 1 or more weekly samples with leukocytosis and neutrophilia, ${ }^{1}$ or with serum haptoglobin or serum amyloid $\alpha$ above their respective clinical reference ranges ${ }^{2}$ during wk 1 to 6 of lactation, for cows calving at BCS (10-point scale; Roche et al., 2004) 5.5 (high), 4.5 (medium), and 3.5 (low)

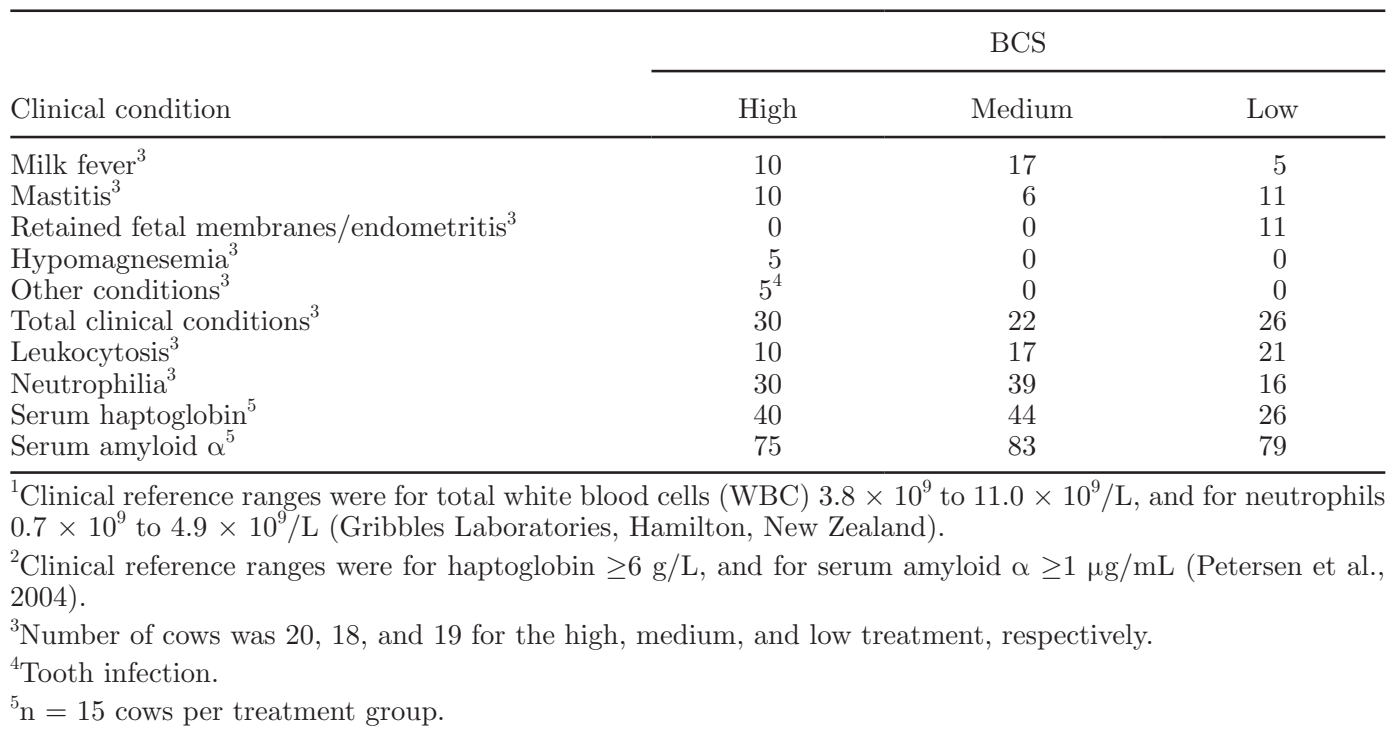
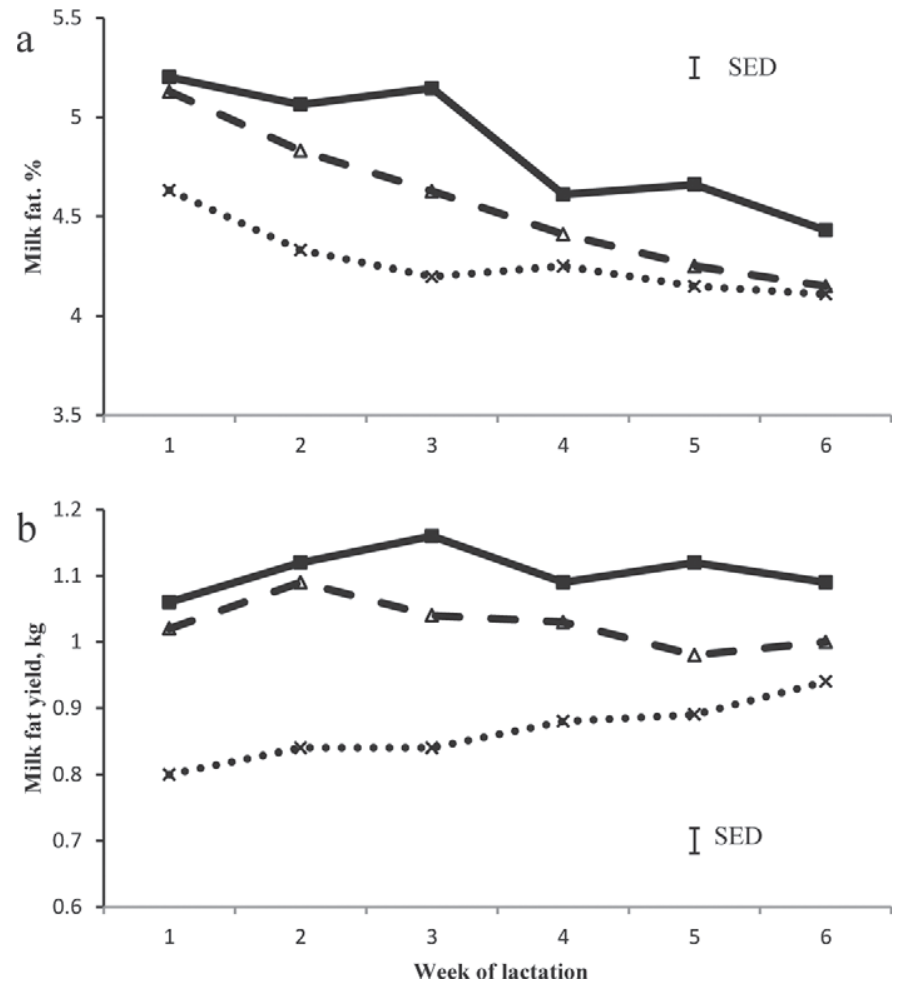

Figure 2. Mean milk fat percent $(\mathrm{a} ; \%)$ and yield $(\mathrm{b} ; \mathrm{kg} / \mathrm{d})$ during wk 1 to 6 of lactation from cows calving at BCS (10-point scale; Roche et al., 2004) 5.5 (high; - - ; $\mathrm{n}=20$ ), 4.5 (medium; - - $\Delta--; \mathrm{n}=$ 18 ), and 3.5 (low; $\cdots \times \cdots ; \mathrm{n}=19$ ). Error bars represent the SE of the difference (SED). treatment than the other 2 groups, which did not differ from each other (Table 5). There was a treatment by time interaction $(P<0.05)$, such that concentrations decreased in the medium group between wk -2 and -1 , but remained constant in the other groups. Individual prepartum plasma BHBA concentrations were all $<1.1$ mmol/L. Mean plasma glucose and NEFA concentrations (Table 5) did not differ by treatment prepartum.

After calving, circulating concentrations of BHBA and NEFA increased with BCS $(P<0.001$; Table 5$)$, consistent with a greater BCS loss with increasing calving BCS reported here and elsewhere (Broster and Broster, 1998; Roche et al., 2009) and the treatment by time effect on BW. Mean plasma glucose concentrations did not differ between treatments after calving (Table 5). Figure 3(a-c) depicts the proportions of cows in each treatment group for which individual values of energy metabolism indicators fell outside the clinical range in each postpartum week. Plasma concentrations of BHBA $\geq 1.4 \mathrm{mmol} / \mathrm{L}$ and NEFA $>1 \mathrm{mmol} / \mathrm{L}$ were more frequent in the high-BCS group (Figure 3a and b), with cows in the medium- and low-BCS groups differing little throughout the measurement period. The proportions of cows with plasma glucose concentrations $\leq 3 \mathrm{mmol} / \mathrm{L}$ were similar for all BCS groups (Figure $3 \mathrm{c}$ ). These data reflect a nonlinear effect of calving BCS on the risk of metabolic diseases associated with negative energy balance. Garnsworthy (2006) concluded that cows that were excessively fat were at an increased risk of fatty liver and ketosis because of the DMIsuppressing effects of high BCS and the excessive BCS 


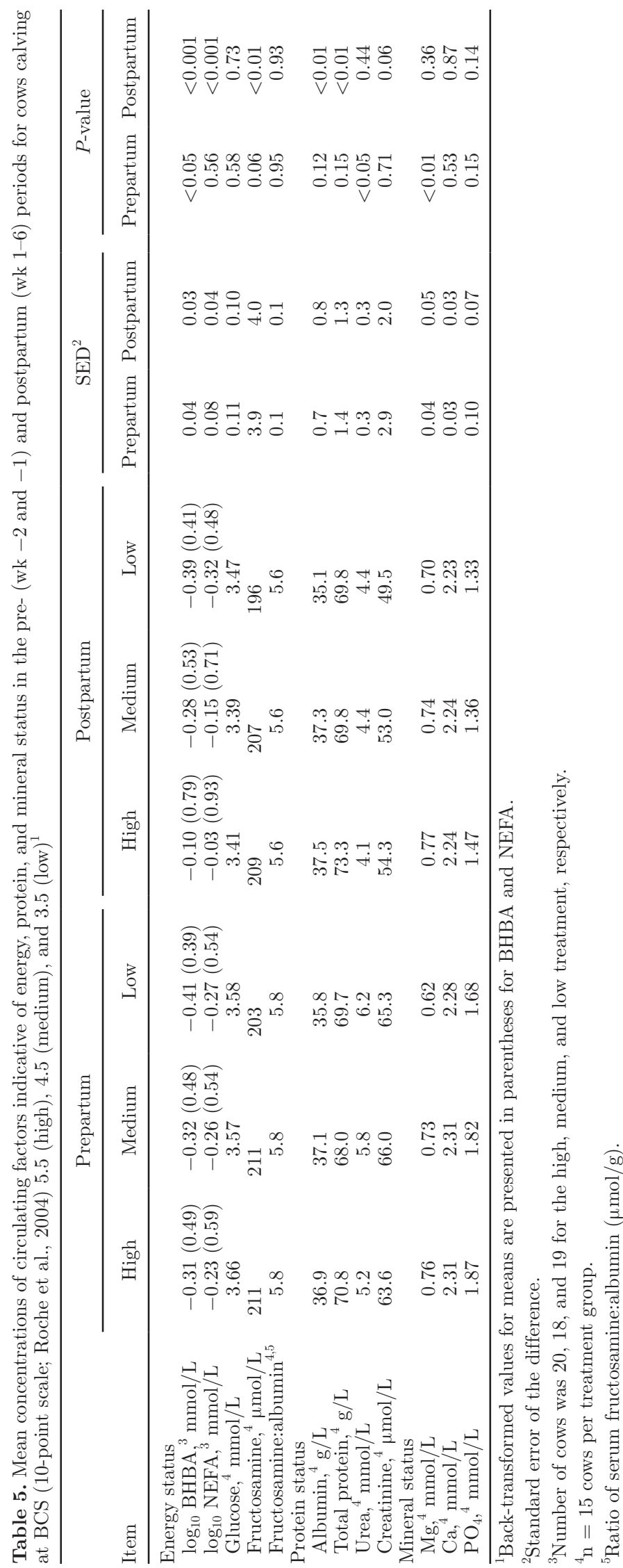

mobilization in early lactation in these cows. Similarly, Gillund et al. (2001) reported a doubling of the risk of ketosis in dairy cows calving at a BCS >6.0 (10-point scale) compared with more moderately conditioned animals (BCS 5.5). The data presented here reflect a major increase in the risk of subclinical ketosis, at least, in dairy cows that calved at BCS 5.5 compared with those that calved at 4.5 , with no difference in the risk at BCS 4.5 or 3.5. This is consistent with the $50 \%$ increase in mean BHBA concentrations in the high-BCS cows compared with the medium-BCS cows. To avoid ketosis, it is imperative that BCS is managed in mid to late lactation and during the nonlactating period to ensure that cows do not get even moderately fat. Roche et al. (2009) concluded that a BCS of 5.0 at calving was an effective compromise between the production and fertility benefits associated with increasing BCS and the increased risk of negative energy balance-related health disorders.

The effect of BCS on serum fructosamine was nonlinear, with concentrations less in low-BCS cows than the other 2 treatment groups before and after calving; however, the fructosamine-to-albumin ratio was not affected by treatment. A postpartum treatment by time interaction $(P<0.01)$ was, however, observed with concentrations in the high and medium groups, declining with DIM, whereas concentrations in the low group remained relatively constant (Figure 4). Serum fructosamines are formed by glycation of circulating proteins, particularly albumin, and the level of protein glycation is proportional to the concentration of plasma glucose (Armbruster, 1987). In monogastric animals, plasma albumin made primarily in the liver has a half-life in circulation of around $21 \mathrm{~d}$; thus, serum fructosamine concentrations may reflect circulating glucose concentrations over the previous 3 to 4 wk. In theory, therefore, undernutrition, sufficient to induce periods of hypoglycaemia, should lead to reduced serum fructosamine concentrations (Agenäs et al., 2006; Strydom et al., 2008; Sorondo and Cirio, 2009; Stengärde et al., 2010). However, this does not explain the tendency for low serum fructosamine in low-BCS cows in the present study, as energy balance was similar in all groups during the 4 wk before calving and blood glucose concentrations were not affected by treatment. It is plausible that the low serum fructosamine concentrations in the low-BCS cows are a reflection of the low albumin concentrations measured in these cows, as fructosamine-to-albumin ratio was not affected by BCS. Agenäs et al. (2006) reported a negative relationship between BCS and the fructosamine:albumin ratio in data derived from normal and drought-affected beef suckler cows. They proposed a threshold of $\geq 10.75$ $\mu \mathrm{mol} / \mathrm{g}$ as representative of historical undernutrition. 

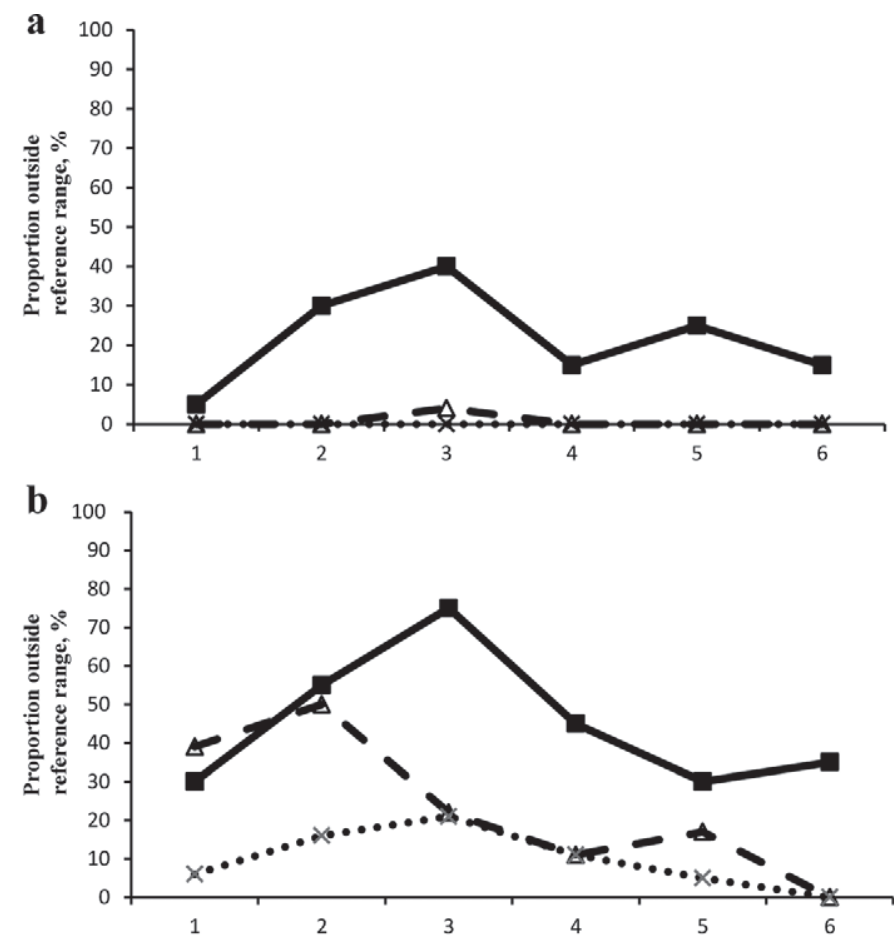

c

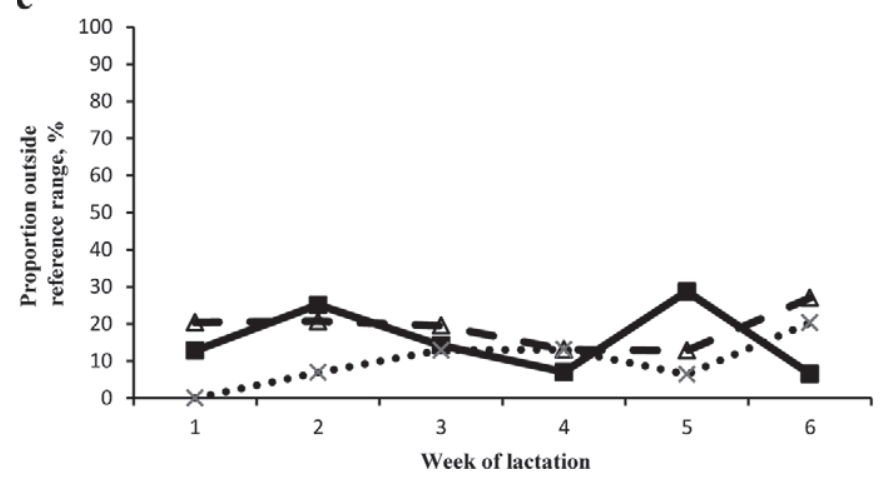

Figure 3. Proportions of cows $(\mathrm{n}=15$ per treatment) with plasma concentrations of BHBA $\geq 1.4 \mathrm{mmol} / \mathrm{L}$ (a), NEFA $>1 \mathrm{mmol} / \mathrm{L}(\mathrm{b}$ ), and glucose $\leq 3 \mathrm{mmol} / \mathrm{L}(\mathrm{c})$, during wk 1 to 6 of lactation when calving at BCS (10-point scale; Roche et al., 2004) 5.5 (high; --), 4.5 (medium; - $-\Delta--$ ), and 3.5 (low; $\cdots \times \cdots$ ).

In the current study, treatment did not affect the ratio of serum fructosamine:albumin (Table 5) and the measured ranges of 5.2 to 6.4 , and 4.7 to $6.6 \mu \mathrm{mol} / \mathrm{g}$, for the pre- and postpartum periods, respectively, never approached the threshold proposed by Agenäs et al. (2006). This suggests that, despite differences in total DMI persisting between treatment groups as calving approached (Table 1), cows in all groups maintained adequate circulating plasma glucose concentrations, reflective of the lack of treatment effect on precalving energy balance. Alternatively, it may be that these metabolites and their ratio are not suitable for determining long-term nutritive status in pasture-based cows.

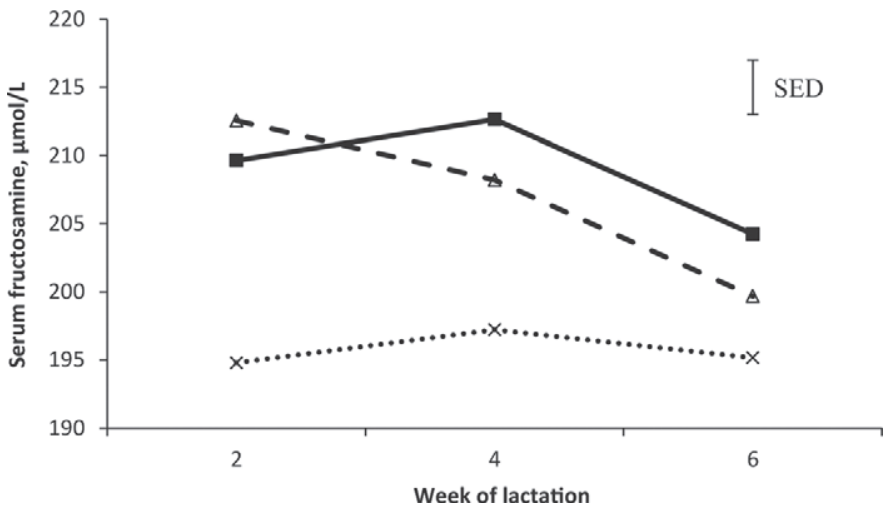

Figure 4. Mean serum fructosamine concentrations $(\mu \mathrm{mol} / \mathrm{L} ; \mathrm{n}=$ 15 cows per treatment) in wk 2,4 and 6 of lactation from cows calving at BCS (10-point scale; Roche et al., 2004) 5.5 (high; - - $), 4.5$ (medium; - $-\Delta--$ ), and 3.5 (low; $\cdots \times \cdots$ ) during the transition period. Error bar represents the SE of the difference (SED).

Indeed Strydom et al. (2008) reported that plasma albumin concentrations may predict severe undernutrition better than the fructosamine:albumin ratio. Albumin concentration has been used as a marker of inflammatory status and liver function postpartum (Bertoni et al., 2008). The pre- and postpartum concentrations evident in the present study are above those indicative of optimal liver function (Bertoni et al. 2008). Thus, the albumin concentrations alone did not suggest that calving BCS was associated with poor liver function.

In summary, although we were unable to measure energy balance in this study, BCS, BW, and the biochemistry results are consistent with a negative relationship between calving BCS and early-lactation energy balance; fatter cows lost more BCS and BW after calving. These changes reflect the expected homeorhetic adaptations associated with differing adiposity at calving, as do the differences in milk production during early lactation. Indicators of energy status provide evidence that cows calving at BCS 3.5 retain some reserve adipose tissue that can be mobilized during lactogenesis. This is consistent with the observation that BCS and depots of inter- and intramuscular fat are poorly correlated and that major internal adipose tissue depots contain 35 to $45 \%$ of body fat (Gregory et al., 1998; Roche et al., 2009). The positive association between calving BCS and plasma concentrations of NEFA and BHBA, and the proportion of cows within BCS groups above thresholds considered to indicate risk of developing metabolic disease confirms the need for a moderate calving BCS to avoid metabolic disorders, while achieving satisfactory levels of milk production (Roche et al., 2009).

\section{Liver Enzymes}

In addition to albumin, the enzymes ASAT, GDH, and GGT were measured as indicators of liver function. 
Although a general trend existed for liver enzyme concentrations to be greater during the postpartum period, serum GGT, ASAT, and GDH concentrations did not differ between BCS treatments (Table 6). A tendency $(P=0.08)$ was observed for a treatment by time interaction after calving, such that serum GGT concentrations increased in the low group, whereas they stayed relatively constant in the other groups. Whether this interaction has biological significance in the context of liver function is not clear from the current data set.

\section{Indicators of Protein Metabolism}

Serum concentrations of urea, creatinine, TP, and albumin were assessed as indicators of protein metabolism. No effect was observed of treatment on mean serum TP concentrations in the prepartum period (Table $5)$, but a tendency $(P<0.1)$ was observed for a treatment by time interaction. Mean serum TP concentrations decreased by $6 \mathrm{~g} / \mathrm{L}$ between wh -2 and -1 in the high- and medium-BCS groups, whereas the equivalent decrease in the low group was only $3 \mathrm{~g} / \mathrm{L}$. This may be a consequence of greater movement of protein components into the udder as parturition approached in the better-conditioned cows, as was reflected in their greater milk protein production after calving. In the postpartum period, mean serum TP concentrations were higher $(P<0.01)$ in the high-BCS group than the other 2 groups, which did not differ from each other (Table 5); this difference probably reflects the difference in labile protein stores with greater BCS.

Serum urea concentrations largely reflect dietary protein inputs but may increase during periods of negative energy balance as muscle tissue is utilized to support metabolism. Mean prepartum serum urea concentrations were highest in the low treatment and lowest in the high treatment, with the medium treatment intermediate $(P<0.05$; Table 5$)$. Although all were within the clinical reference range for pasture-fed dairy cows (2.9-8.8 mmol/L; Malmo et al., 2010), this effect of treatment suggests that prepartum BCS may have influenced protein metabolism. Total DMI (and, consequently, rumen-degradable protein intake) were lower for cows in the low treatment before calving (Table 1), so the higher serum urea concentrations are unlikely to be ruminal in origin. The similarity between groups in serum creatinine and TP concentrations, however, are not consistent with treatment effects on muscle tissue mobilization. The data, therefore, suggest differences in either hepatic production or renal clearance of urea associated with prepartum BCS (e.g., precalving blood urea-to-creatinine ratio decreases with increasing BCS), although treatment differences in the contribution of muscle catabolism cannot be dismissed. After calving,

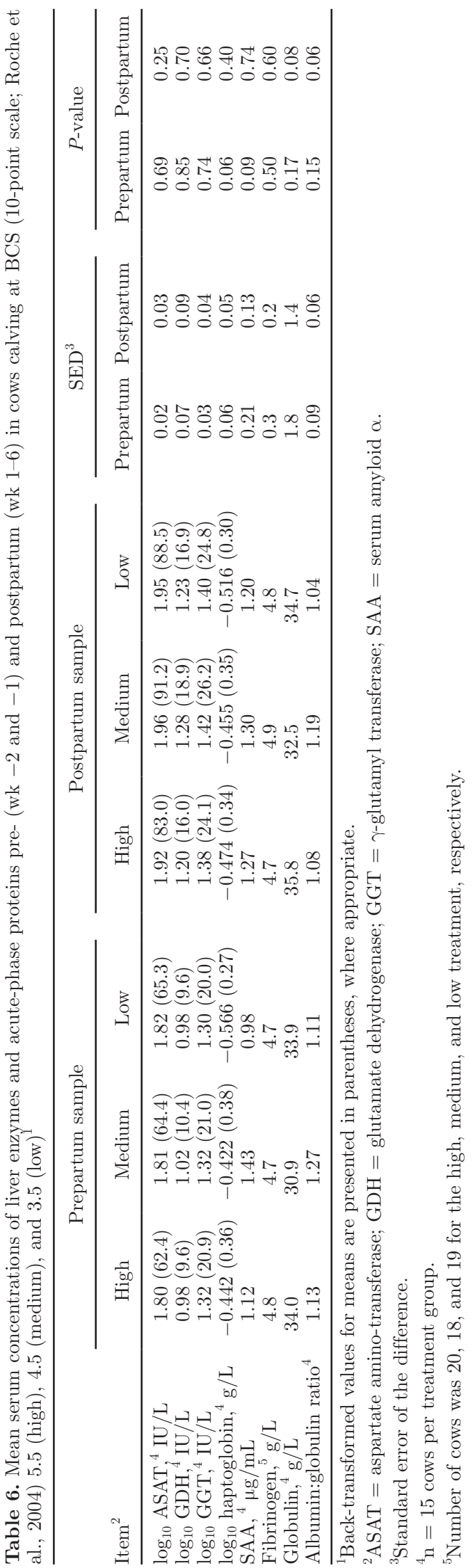

Journal of Dairy Science Vol. 96 No. 9, 2013 
serum urea concentrations were generally lower and did not differ by BCS treatment.

Mean serum albumin and creatinine concentrations were not affected by BCS prepartum, but were lower $(P$ $<0.01)$ in the low group than in the other treatments after calving (Table 5). Low serum albumin concentrations could be a consequence of demand exceeding production or of reduced production. If metabolic reserves are limited, then albumin may be diverted to maintain plasma glucose concentrations in support of udder function. Albumin may also be sequestered in sites of inflammation, [i.e., in its role as a negative acute-phase protein (APP); Burke et al., 2010]. In the immediate postpartum period, the involuting uterus could increase demand in this way. Albumin production may also be directly compromised in the transitioning cow as a consequence of hepatic inflammation associated with the liver's obligation to process triglyceride released from adipose depots (Loor et al., 2007; Bertoni et al., 2008), although this should not result in lower serum albumin in low-BCS cows. The reason for this effect of BCS on serum albumin concentration is not known. Low serum creatinine concentrations are associated with reduced muscle mass (Cozzi et al., 2011); it is probably reflective of the reduced muscle mass in the low-BCS cows and is consistent with the lower serum TP and albumin concentrations.

Serum creatinine and albumin concentrations have been proposed as markers of long-term undernutrition because of their positive relationships with BCS (Agenäs et al., 2006; Strydom et al., 2008), with the latter authors suggesting that serum albumin concentrations $\leq 31.5 \mathrm{~g} / \mathrm{L}$ indicate severe undernutrition in beef cattle. Malmo et al. (2010) proposed that serum albumin concentrations $<27.8 \mathrm{~g} / \mathrm{L}$ represent clinical hypoalbuminemia in dairy cows. Although neither threshold was reached in the current study, the collective data reflect a role for creatinine and albumin in determining long-term nutrition status.

Overall, these data indicate that cows in the low treatment had reduced protein stores in the periparturient period, compared with cows in the medium and high treatments. Although this may have influenced production levels, these effects did not compromise normal function.

\section{APP}

The acute-phase response (APR) is an early component of the nonspecific innate immune response, initiated by proinflammatory cytokines released from macrophages and monocytes at sites of infection or tissue damage (Carroll et al., 2009). Proinflammatory cytokines bind to hepatocyte receptors to upregulate production of positive APP including haptoglobin, SAA, and fibrinogen. Many APP modulate immune cell function and play an active role in tissue repair (e.g., haptoglobin binds hemoglobin from damaged erythrocytes to restrict availability of free iron for bacterial growth, and SAA is antipyretic and inhibits oxidative burst of neutrophilic granulocytes; Petersen et al., 2004). In comparison, albumin is considered a negative APP, as circulating concentrations can decrease by 10 to $30 \%$ when an APR is initiated (Murata et al., 2004; Petersen et al., 2004). Elevated serum globulin concentrations and the ratios of serum globulin:albumin indicate response of the adaptive immune system, in particular lymphocyte proliferation and increased levels of circulating antibodies (Malmo et al., 2010). Although not components of the APR, they were measured as general indicators of adaptive immune response.

Although serum fibrinogen was not affected by BCS treatment, mean serum haptoglobin and SAA concentrations tended $(P<0.10)$ to be affected by cow BCS in the prepartum period, but did not differ postpartum (Table 6). In addition, the effect of BCS on the concentrations of these positive APP was not linear, with lower concentrations in the low-BCS cows than the medium-BCS cows, and the high-BCS cows intermediate. It is not clear why low BCS would result in a decrease in the APR, but the effect was small and possibly biologically insignificant. Reports quantifying haptoglobin as an estimate of risk for periparturient disease have concluded that concentrations greater than 0.8 to $1.0 \mathrm{~g} / \mathrm{L}$ represent high risk (Huzzey et al., 2009; Dubuc et al., 2010). Overall, the concentrations of haptoglobin in this experiment were 30 to $50 \%$ of this range, reflecting a low risk of periparturient disease. In comparison, however, mean SAA concentrations were consistently double the concentration, signaling activation of an APR $(>1 \mu \mathrm{g} / \mathrm{mL}$; Karreman et al., 2000). In fact, concentrations $\geq 2 \mu \mathrm{g} / \mathrm{mL}$ were measured in $29 \%$ of individual samples, with most cows having at least 1 sample in which it was exceeded (Table 4). The pattern of response was that, once elevated, high concentrations persisted for several weeks. Haptoglobin and SAA concentrations were associated with $\log _{10} \mathrm{SCC}\left(\mathrm{R}^{2}=0.35\right.$ and 0.26 , respectively; $P<0.05$ ), but not with uterine PMNL percentage $\left(\mathrm{R}^{2}=0.02\right.$ and -0.01 , respectively; $P>0.05)$. Of 12 cows in which SAA concentrations $\geq 2 \mu \mathrm{g} / \mathrm{mL}$ were recorded in multiple samples, 7 were related to clinical conditions.

A tendency existed for treatment to affect mean serum globulin concentrations, such that cows in the medium treatment had lower mean concentrations than the other 2 groups, which were similar $(P=0.08$; 
Table 6). The mean ratio of serum albumin:globulin also tended to be higher in the medium group $(P=$ 0.06; Table 6).

In summary, although the time profiles of the APR to single insults have not been fully characterized, peak concentrations of individual APP generally develop over time courses of 0.25 to $3 \mathrm{~d}$ (Karreman et al., 2000; Carroll et al., 2009). Although the weekly sampling protocol used for this investigation limits interpretation of the data to a general indication of background activation of the APR rather than response to specific insults, when all APP results are considered together, the conclusion must be that cows from all BCS treatment groups were able to mount an effective APR (i.e., cows in the low treatment were not compromised in this functional characteristic) and that cows experienced similar levels of APR activation irrespective of BCS treatment. A state of generalized immune system activation is normal for transition cows, as they are exposed to a wide variety of challenges that influence the onset of inflammatory conditions, including elevated plasma cortisol concentrations during parturition, mammary gland edema, calving trauma, and uterine involution (Loor et al., 2007; Trevisi et al., 2009). Serum amyloid $\alpha$ provided the best indication of clinical conditions in the current study, although these only explained around half of the observed occurrences of elevated SAA.

\section{Indicators of Mineral Metabolism}

The only effect of BCS treatment on serum Mg concentrations occurred in the prepartum period, when levels were lower in the low group than in medium and high groups, which were similar $(P<0.01$; Table $5)$. The reason for this effect of treatment on $\mathrm{Mg}$ is not known. Burke et al. (2010) reported differences in postpartum $\mathrm{Mg}$ concentrations in cows with subclinical endometritis and hypothesized that this reflected liver dysfunction in these cows. Bertoni et al. (2008) also reported depressed plasma $\mathrm{Mg}$ concentrations in cows with impaired liver function. However, none of the parameters measured indicate prepartum liver dysfunction, making this an unlikely reason for the recorded difference in serum $\mathrm{Mg}$ concentrations. $\mathrm{As} \mathrm{Mg}$ is not stored, circulating concentrations usually reflect daily intakes. It is, therefore, most likely that the lower levels reflect the lower DMI of cows in the low treatment in the weeks before calving (Table 1).

Serum Ca concentrations did not differ between treatment groups. A calving BCS that exceeds recommendations at calving is widely recognized as a risk factor for milk fever in transition dairy cows (Heuer et al., 1999; Roche and Berry, 2006; Roche et al., 2009).
Although numbers within treatment groups were insufficient to determine differences in the occurrence of clinical milk fever (Table 4), the overall similarity of serum concentrations between treatment groups for mineral metabolism markers indicates that, within the BCS range investigated, the risk of milk fever was similar. Mean calving BCS for the high group was 5.2 $[\mathrm{SE}$ of the difference $(\mathrm{SED})=0.05]$, with the range constrained by the preparation procedures. At this level, they conformed to management recommendations for calving BCS, rather than exceeding it substantially. At this level of adiposity, the risk of milk fever is unlikely to be increased (Roche and Berry, 2006).

\section{Other Indicators of Health}

Treatment did not affect mean quarter SCC in samples taken at the tenth milking $\left(\log _{10}\right.$-transformed means: $1.77,1.81$, and 1.70 for high, medium, and low treatments, respectively; SED $=0.15)$. Nor did treatment affect mean SCC in samples during week 1 to 6 ( $\log _{10}$-transformed means: 1.80, 1.89, and 1.76 for high, medium, and low treatments, respectively; SED $=0.12)$. Similarly, the frequency of culture-positive milk samples did not differ between treatment groups. Overall $18 / 224(8.0 \%)$ and $5 / 228(2.2 \%)$ of samples from the first and tenth milkings, respectively, were culture positive, with Streptococcus uberis being the predominant pathogen isolated from 11/18 (61\%) and $3 / 5(60 \%)$ of culture-positive first and tenth milking samples, respectively.

An effect of treatment was observed on the mean proportions of PMNL in the endometrial cytology smear in wk 4 postcalving, when the low treatment group tended to have higher mean PMNL percentage than the other groups, which were similar $(P<0.10$; Table 7). In wk 6 postcalving, high-BCS cows had lower PMNL percentage than the other groups, which were similar $(P<0.01$; Table 7$)$. Low calving BCS has been previously recognized as a risk factor for endometritis (McDougall et al., 2011); however, the data presented here indicate causality, with low-BCS cows presenting with higher uterine PMNL percentage than high-BCS cows. The proportion of PMNL exceeding $7 \%$ of cells (representing greater likelihood of endometritis; McDougall et al., 2011) in 41 individual samples from 29 cows are also consistent with a positive effect of calving BCS on uterine health $(7,9$, and 13 cows from the high, medium, and low treatments, respectively, exceeded the $7 \%$ threshold).

The proportions of cows with observed premating heats and the proportions pregnant after $67 \mathrm{~d}$ of mating did not vary by treatment (Table 7). A tendency existed for the mean interval from calving to conception 
Table 7. Mean proportions of PMNL in uterine secretions during wk 2, 4, and 6 of lactation, and reproductive performance measures for cows calving at BCS (10-point scale; Roche et al., 2004) 5.5 (high; $\mathrm{n}=20), 4.5$ (medium; $\mathrm{n}=18$ ), and $3.5(\text { low; } \mathrm{n}=19)^{1}$

\begin{tabular}{|c|c|c|c|c|c|}
\hline Item & \multicolumn{3}{|c|}{ BCS } & SED & $P$-value \\
\hline wk 2 & 11.1 & 17.0 & 18.0 & 2.7 & 0.30 \\
\hline wk 4 & 8.0 & 10.2 & 15.9 & 3.5 & $<0.01$ \\
\hline wk 6 & 2.1 & 8.1 & 8.7 & 3.4 & $<0.01$ \\
\hline $\log _{10}$ interval calving to conception, $\mathrm{d}$ & $1.99(98)$ & $2.09(122)$ & $2.02(105)$ & 0.042 & 0.08 \\
\hline
\end{tabular}

${ }^{1}$ Proportional data for PMNL percentage were angular transformed before analysis; means and SE of the difference (SED) are presented as transformed values. Interval data were $\log _{10}$ transformed before analysis. Back-transformed values are presented in parentheses.

to vary with treatment, being longer for the medium group than the other 2 groups, which were similar $(P=$ 0.08; Table 7). An effect of treatment was observed on the mean interval from the start of mating to conception $(P<0.05$; Table 7$)$, with the interval shortest for the high-BCS group and longest for the medium-BCS group. Reproductive performance data must be interpreted with caution because cow numbers limit power to detect treatment differences, and mating strategies varied between individuals. Nevertheless, these data are consistent with the reported relationship between peripartum BCS and reproductive success in pasture-based cows, in which lower BCS is associated with delays in the resumption of estrus cycles and reduced odds of pregnancy to first service (Roche et al., 2009).

\section{CONCLUSIONS}

Milk production and the extent of the early-lactation negative energy balance increased with calving BCS. Low peripartum BCS was associated with alterations in albumin, urea, and $\mathrm{Mg}$ metabolism, which may place cows at a greater risk of developing subclinical endometritis. Biomarkers of liver function and the APR suggest that BCS did not affect the cows' ability to mount inflammatory responses to the stimuli encountered peripartum and during early lactation. Application of these results to the health status of cows with low BCS in commercial dairy cows must be guarded, as low BCS cows in those circumstances may have preexisting disease, and daily DMI is often more variable. Nevertheless, these results support general recommendations that a calving BCS of 4.5 to 5.5 (10-point scale) will optimize production, reproductive performance, and general health, but that BCS is not a sufficiently sensitive measure to be reflective of cow welfare.

\section{ACKNOWLEDGMENTS}

The authors acknowledge the significant support of Alan Napper and Jessica Morse (DairyNZ, Hamilton,
New Zealand) for on-farm logistics; Bruce Sugar and the DairyNZ Lye Dairy Farm team for their management and care of animals; Gemma Worth, Suzanne Dowling, and Francis Huddart (AgResearch, Hamilton, New Zealand); and Kate Watkins, Kirsty McLeod, Nicola Priest, Viliami Taufa, and Mark Bryant (DairyNZ) for technical support. Thanks are due to Alison Cullum from AgResearch for advice and clinical health assessments. The authors also acknowledge the laboratory expertise of John Williamson, Elena Minnee, and Doreen Day (DairyNZ); Beth Woodgate, Bronwyn Harrop, and Wendy Palmer (Gribbles Laboratories, Hamilton, NZ), and Kelly Buckle (Massey University, Palmerston North, New Zealand). The authors thank Barbara Dow (DairyNZ) for statistical analysis. This project was funded by the Ministry for Business, Innovation and Employment (Wellington, New Zealand; contract numbers C10X0813 and UoAX0814) and New Zealand dairy farmers through DairyNZ Inc. (contract numbers AW805, AW806, and AN808).

\section{REFERENCES}

Agenäs, S., M. F. Heath, R. M. Nixon, J. M. Wilkinson, and C. J. C. Phillips. 2006. Indicators of undernutrition in cattle. Anim. Welf. 15:149-160.

Armbruster, D. A. 1987. Fructosamine: Structure analysis and clinical usefulness. Clin. Chem. 33:2153-2163.

Barlund, C. S., T. D. Carruthers, C. L. Waldner, and C. W. Palmer. 2008. Comparison of diagnostic techniques for postpartum endometritis in dairy cattle. Theriogenology 69:714-723.

Berry, D. P., F. Buckley, P. Dillon, R. D. Evans, M. Rath, and R. F. Veerkamp. 2003. Genetic parameters for body condition score, body weight, milk yield, and fertility estimated using random regression models. J. Dairy Sci. 86:3704-3717.

Berry, D. P., J. M. Lee, K. A. Macdonald, K. Stafford, L. Matthews, and J. R. Roche. 2007. Associations between body condition score, somatic cell count, and clinical mastitis in seasonally calving dairy cattle. J. Dairy Sci. 90:637-648.

Bertoni, G., E. Trevisi, X. Han, and M. Bionaz. 2008. Effects of inflammatory conditions on liver activity in puerperium period and consequences for performance in dairy cows. J. Dairy Sci. 91:3300-3310.

Broster, W. H., and V. J. Broster. 1998. Body score of dairy cows. J. Dairy Res. 65:155-173.

Burke, C. R., S. Meier, S. McDougall, C. Compton, M. Mitchell, and J. R. Roche. 2010. Relationships between endometritis and meta- 
bolic state during the transition period in pasture-grazed dairy cows. J. Dairy Sci. 93:5363-5373.

Carroll, J. A., R. R. Reuter, C. C. Chase Jr., S. W. Coleman, D. G. Riley, D. E. Spiers, J. D. Arthington, and M. L. Galyean. 2009. Profile of the bovine acute-phase response following an intravenous lipopolysaccharide challenge. Innate Immun. 15:81-89.

Coffey, M. P., G. Simm, J. D. Oldham, W. G. Hill, and S. Brotherstone. 2004. Genotype and diet effects on energy balance in the first three lactations of dairy cows. J. Dairy Sci. 87:4318-4326.

Cozzi, G., L. Ravarotto, F. Gottardo, A. L. Stefani, B. Contiero, L. Moro, M. Brscic, and P. Dalvit. 2011. Short communication: Reference values for blood parameters in Holstein dairy cows: Effects of parity, stage of lactation, and season of production. J. Dairy Sci. 94:3895-3901.

Drackley, J. K., T. R. Overton, and G. N. Douglas. 2001. Adaptations of glucose and long-chain fatty acid metabolism in liver of dairy cows during the periparturient period. J. Dairy Sci. 84(E. Suppl.):E100-E112.

Dubuc, J., T. F. Duffield, K. E. Leslie, J. S. Walton, and S. J. LeBlanc. 2010. Risk factors for postpartum uterine diseases in dairy cows. J. Dairy Sci. 93:5764-5771.

Garnsworthy, P. C. 2006. Body condition score in dairy cows: Targets for production and fertility. Pages $61-86$ in Recent Advances in Animal Nutrition. P. C. Garnsworthy and J. Wiseman, ed. Nottingham University Press, UK.

Gillund, P., O. Reksen, Y. T. Gröhn, and K. Karlberg. 2001. Body condition related to ketosis and reproductive performance in Norwegian dairy cows. J. Dairy Sci. 84:1390-1396.

Gregory, N. G., J. K. Robins, D. G. Thomas, and R. W. Purchas. 1998. Relationship between body condition score and body composition in dairy cows. N. Z. J. Agric. Res. 41:527-532.

Heuer, C., Y. H. Schukken, and P. Dobbelaar. 1999. Postpartum body condition score and results from the first test day milk as predictors of disease, fertility, yield, and culling in commercial dairy herds. J. Dairy Sci. 82:295-304.

Hogan, J. S., R. N. Gonzalez, R. J. Harmon, S. C. Nickerson, S. P. Oliver, J. W. Pankey, and K. L. Smith. 1999. Laboratory Handbook on Bovine Mastitis. Natl. Mastitis Counc. Inc., Madison, WI.

Huzzey, J. M., T. F. Duffield, S. J. LeBlanc, D. M. Veira, D. M. Weary, and M. A. G. von Keyserlingk. 2009. Short communication: Haptoglobin as an early indicator of metritis. J. Dairy Sci. 92:621-625.

Huzzey, J. M., D. M. Veira, D. M. Weary, and M. A. G. von Keyserlingk. 2007. Prepartum behavior and dry matter intake identify dairy cows at risk for metritis. J. Dairy Sci. 90:3220-3233.

Ingvartsen, K. L., R. J. Dewhurst, and N. C. Friggens. 2003. On the relationship between lactational performance and health: Is it yield or metabolic imbalance that cause production diseases in dairy cattle? A position paper. Livest. Prod. Sci. 73:277-308.

Karreman, H. J., G. H. Wentink, and T. Wensing. 2000. Using serum amyloid A to screen dairy cows for sub-clinical inflammation. Vet. Q. 22:175-178.

Lacetera, N., D. Scalia, U. Bernabucci, B. Ronchi, D. Pirazzi, and A. Nardone. 2005. Lymphocyte functions in overconditioned cows around parturition. J. Dairy Sci. 88:2010-2016.

Loor, J. J., H. M. Dann, N. A. Janovick Guretzky, R. E. Everts, R. Oliveira, C. A. Green, N. B. Litherland, S. L. Rodriguez-Zas, H. A. Lewin, and J. K. Drackley. 2006. Plane of nutrition prepartum alters hepatic gene expression and function in dairy cows as assessed by longitudinal transcript and metabolic profiling. Physiol. Genomics 27:29-41.

Loor, J. J., R. E. Everts, M. Bionaz, H. M. Dann, D. E. Morin, R. Oliveira, S. L. Rodriguez-Zas, J. K. Drackley, and H. A. Lewin. 2007. Nutrition-induced ketosis alters metabolic and signaling gene networks in liver of periparturient dairy cows. Physiol. Genomics 32:105-116.
Macdonald, K., and J. R. Roche. 2004. Condition Scoring Made Easy. DairyNZ, Hamilton, New Zealand.

Malmo, J., J. J. Vermunt, and T. J. Parkinson. 2010. Clinical examination. Pages 33-74 in Diseases of Cattle in Australasia. VetLearn, Wellington, New Zealand.

Markusfeld, O. 1985. Relationship between overfeeding, metritis and ketosis in high yielding dairy cows. Vet. Rec. 116:489-491.

Matthews, L. R., C. Cameron, A. J. Sheahan, E. S. Kolver, and J. R. Roche. 2012. Associations among dairy cow body condition and welfare-associated behavioral traits. J. Dairy Sci. 95:2595-2601.

McDougall, S., H. Hussein, D. Aberdein, K. Buckle, J. Roche, C. Burke, M. Mitchell, and S. Meier. 2011. Relationships between cytology, bacteriology and vaginal discharge scores and reproductive performance in dairy cattle. Theriogenology 76:229-240.

Millar, H. R., J. G. Simpson, and A. L. Stalker. 1971. An evaluation of the heat precipitation method for plasma fibrinogen estimation. J. Clin. Pathol. 24:827-830.

Murata, H., N. Shimada, and M. Yoshioka. 2004. Current research on acute phase proteins in veterinary diagnosis: An overview. Vet. J. $168: 28-40$.

Petersen, H. H., J. P. Nielsen, and P. M. H. Heegaard. 2004. Application of acute phase protein measurements in veterinary clinical chemistry. Vet. Res. 35:163-187.

Rafia, S., T. Taghipour-Bazargani, Z. Khaki, S. Bokaie, and S. S. Tabrizi. 2012. Effect of body condition score on dynamics of hemogram in periparturient Holstein cows. Comp. Clin. Pathol. 21:933-943.

Roche, J. R., and D. P. Berry. 2006. Periparturient climatic, animal, and management factors influencing the incidence of milk fever in grazing systems. J. Dairy Sci. 89:2775-2783.

Roche, J. R., P. G. Dillon, C. R. Stockdale, L. H. Baumgard, and M. J. VanBaale. 2004. Relationships among international body scoring systems. J. Dairy Sci. 87:3076-3079.

Roche, J. R., N. C. Friggens, J. K. Kay, M. W. Fisher, K. J. Stafford, and D. P. Berry. 2009. Invited review: Body condition score and its association with dairy cow productivity, health, and welfare. J. Dairy Sci. 92:5769-5801.

Roche, J. R., J. K. Kay, C. V. C. Phyn, S. Meier, J. M. Lee, and C. R. Burke. 2010. Dietary structural to nonfiber carbohydrate concentration during the transition period in grazing dairy cows. J. Dairy Sci. 93:3671-3683.

Sorondo, M. L., and A. Cirio. 2009. Evaluation of serum fructosamine test to monitor the plasma glucose concentration in the transition dairy cow. J. Dairy Res. 76:173-178.

Stengärde, L., K. Holtenius, M. Tråvén, J. Hultgren, R. Niskanen, and U. Emanuelson. 2010. Blood profiles in dairy cows with displaced abomasum. J. Dairy Sci. 93:4691-4699.

Stockdale, C. R. 2001. Body condition at calving and the performance of dairy cows in early lactation under Australian conditions: A review. Aust. J. Exp. Agric. 41:823-829.

Strydom, S., S. Agenäs, M. F. Heath, C. J. Phillips, G. H. Rautenbach, and P. N. Thompson. 2008. Evaluation of biochemical and ultrasonographic measurements as indicators of undernutrition in cattle. Onderstepoort J. Vet. Res. 75:207-213.

Trevisi, E., M. Amadori, A. M. Bakudila, and G. Bertoni. 2009. Metabolic changes in dairy cows induced by oral, low-dose interferonalpha treatment. J. Anim. Sci. 87:3020-3029.

Uribe, H. A., B. W. Kennedy, S. W. Martin, and D. F. Kelton. 1995. Genetic parameters for common health disorders of Holstein cows. J. Dairy Sci. 78:421-430.

Verbyla, A. P., B. R. Cullis, M. G. Kenward, and S. J. Welham. 1999. The analysis of designed experiments and longitudinal data by using smoothing splines. Appl. Stat. 48:269-311.

VSN International Ltd. 2011. GenStat for Windows. 14th ed. VSN International Ltd., Hemel Hempstead, UK. 